\title{
MYOSITIS OSSIFICANS - A CASE REPORT
}

\author{
SULTANA $F^{1}$, QUDDUS MA ${ }^{2}$, RAHMAN MM ${ }^{3}$, NURUZZAMAN SM ${ }^{4}$
}

\begin{abstract}
:
Myositis Ossificans is classified into three types: progressive, post traumatic and paraplegic. The progressive form, myositis ossoificans congenita, is a hereditary disease which is usually autosomal dominant or an isolated mutation and more common in boys. Post-traumatic myositis is found following massive trauma and paraplegic myositis occurs below the level of paralysis. Here, a heterotopic bone formation is evident in the muscle or soft tissue, which can occur almost anywhere in the body. An incidental case of myositis ossificans was found in the Department of Radiology \& Imaging, Dhaka Medical College Hospital, Dhaka in March, 2009. A male patient of 22 years of age was sent for radiological investigations from the medicine out patient department (MOPD) of Dhaka Medical College Hospital, Dhaka having complaints of backache and pain in the neck and chest. He was diagnosed as a case of myositis ossificans after the radiological report. It was an incidental finding having no history of trauma or familial predisposition. This case is presented for journal record and academic interest.
\end{abstract}

Key words: Myositis Ossificans, autosomal dominant.

J Dhaka Med Coll. 2008; 17(2) : 79-81

\section{Introduction:}

Myositis Ossificans is classified into three types: progressive, post-traumatic and paraplegic. The progressive form, myositis ossoificans congenita, is a hereditary disease which is usually autosomal dominant or an isolated mutation and more common in boys ${ }^{1}$. It is a benign non-neoplastic, heterotopic bone formation in the muscle or soft tissue. The lesions are predominantly localized at high-risk sites of injury, such as the thigh, buttocks, elbow, and less often, the shoulder and calf ${ }^{2,3}$. However, myositis ossificans can occur almost anywhere in the body, even in the sternocleidomastoid muscle, paravertebral area, and the muscle of the chest wall ${ }^{4,5,6}$. Posttraumatic myositis results in a soft tissue mass which ossifies with a lacy pattern by 4-8 weeks. Paraplegic myositis develops in paraplegics within 3-4 weeks below the level of the paralysis where heterotopic periarticular calcification and ossification are found ${ }^{1}$.

\section{Case Summary:}

A 22 years old male patient attended the medicine out patient department (MOPD) of Dhaka Medical College Hospital, Dhaka, with the complaints of backache and pain in the neck and chest. He had no history of significant trauma except occasional fall down during playing. He was sent for radiological investigations. His chest radiograph and that of cervical spine were done. The chest radiograph shows ossification of the chest wall muscles on the right and also on the left (Fig.1).

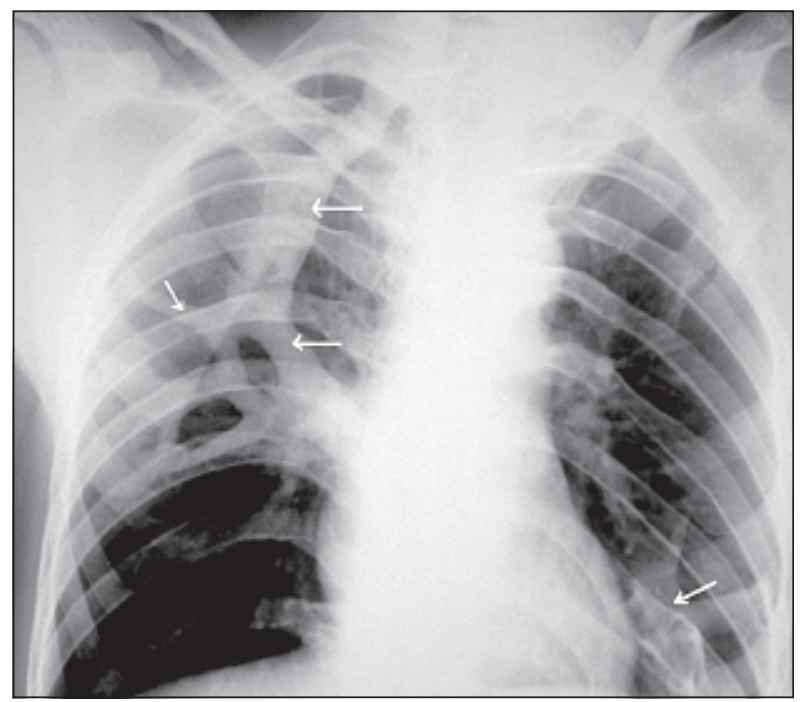

Fig.-1: Chest radiopgraph $(P / A$ view) showing ossification of chest wall muscles (white arrows).

1. Indoor Medical Officer, Department of Radiology \& Imaging, Dhaka Medical College Hospital, Dhaka.

2. Professor and Head, Department of Radiology \& Imaging, Dhaka Medical College \& Hospital, Dhaka.

3. Assistant Professor, Department of Radiology \& Imaging, Dhaka Medical College \& Hospital, Dhaka.

4. Student of MD (Radiology)-thesis part, Department of Radiology \& Imaging, Dhaka Medical College, Dhaka.

Correspondence: Dr. Farhana Sultana 
The radiograph of the lateral view of the cervical spines shows ossification of ligamentum nuchae and the erector spinae muscle with associated block vertebrae in between $\mathrm{C}_{2}$ and $\mathrm{C}_{3}$ (Fig.2). His complete blood count revealed nothing significant except a mild rise in ESR. Routine examination of urine was also done and it gave a normal report. ECG report revealed nothing significant except a mild tachycardia.

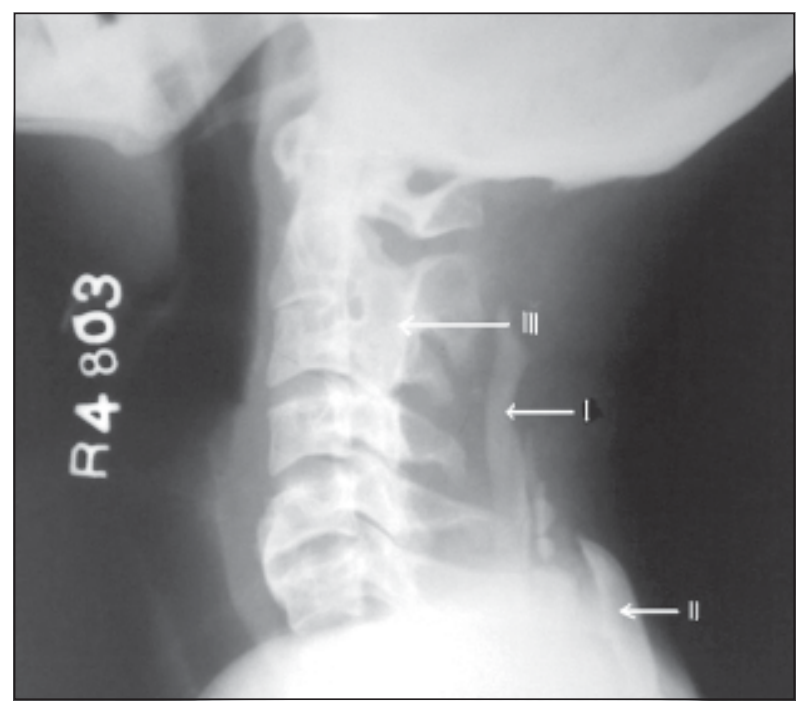

Fig.-2: Radiograph of the cervical spine (lateral view) showing ossification of the ligamentum nuchae (I), Erector spinae (II) and Block vertebrae in between $\mathrm{C}_{2}$ and $\mathrm{C}_{3}$ (III).

\section{Discussion:}

Myositis Ossificans may have autosomal dominant inheritance with complete penetrance but variable expressivity, and most cases result from a sporadic mutation. Genes for bone morphogenetic proteins, in particular BMP4, are thought to be plausible candidate genes. Mutations in the ACVR1 gene cause fibrodysplasia ossificans progressive ${ }^{7}$. Ectopic ossification usually starts in early childhood. Radiological evidence of heterotopic bone formation in the muscle or soft tissue and ossification are not usually present until 4-6 weeks after the appearance of a lump.

\section{Imaging studies ${ }^{7}$ :}

- Plain Radiographs:

o In early disease, radiographs may be normal or show soft-tissue swelling. The most characteristic finding is areas of soft tissue ossification mainly in the paraspinal region.

o Vertebral fusion, vertebral anomalies e.g. small bodies, pedicle thickening can also be seen.

o There is increased incidence of enchondromas.

o Other associated bony abnormalities include short metacarpals and metatarsals, phalangeal synostosis and thick short femoral neck.

- Ultrasonography: Early lesions may show a sonolucent soft tissue mass; calcification within the lesion may also be seen as echogenic and shadowing mass.

- Computerized Tomography: Sensitive for ossification and is the investigation of choice.

- Magnetic Resonance Imaging: Early lesions shows high signal intensity on $\mathrm{T}_{2}$ weighted images associated with proliferating fibroblasts. Early calcification is not typically detectable. Late MRI scans show low $\mathrm{T}_{1}$ and $\mathrm{T}_{2}$ signals associated with fibrous or calcified tissue.

- Bone Scintigraphy: Reveals enhanced uptake in immature lesions. Once the maturation occurs uptake of the lesions become comparable with normal bones.

Histopathology?:

Histologically, early lesions resemble granulation tissue, occasionally with cellular inflammatory infiltrate. Spicules of bone appear in the centre of the fibroblastic nodules. Bone and cartilage formation is seen in mature specimens. The bone formed initially is of the woven type; this is later remodelled to mature lamellar bone.

\section{Management:}

The most common treatment of myositis ossificans is a surgical excision ${ }^{8,9}$. Some studies have proposed close observation because of the self-limiting and benign nature of the disease ${ }^{10}$. However, when myositis ossificans is found in an unusual location including the left paravertebral muscle, chest wall, and abdominal wall, and there is no history 
of trauma that would exclude a malignancy, some investigators have recommended totally removing the mass in order to make a diagnosis ${ }^{11}$. According to some researchers, various treatments such as physical therapy, acetic acid iontophoresis treatment, magnesium therapy, and etidronate disodium have been reported to be effective ${ }^{12,13,14}$. Recurrence is unusual after a complete excision ${ }^{8}$. However, some studies have reported a repeated relapse, and as a result, a surgical excision including the surrounding attached muscle and etidronate disodium supplement to help avoid recurrence were thus recommended in such cases $9,15,16$. In conclusion, myositis ossificans deserves notice in the differential diagnosis of sudden intercostal pain and of a calcified soft tissue mass of the chest wall. Biopsy is not always necessary if a radiologically typical pattern of ossification is present ${ }^{17}$

\section{References:}

1. Jenkins JPR. The soft tissues. In: Sutton D, Robinson PJA, Jenkins JPR, Whitehouse RW, Allan PL, Wilde P, et al. eds. Textbook of radiology and imaging. Vol. 2. $7^{\text {th }}$ ed. Philadelphia: Elsevier Churchill Livingstone; 2002. p.1440-1.

2. Frassica FJ, Thompson RC. Evaluation, diagnosis, and classification of benign soft-tissue tumors. $\mathrm{J}$ Bone Joint Surg Am. 1996; 78: 126-40.

3. Gindele A, Schwamborn D, Tsironis K. Myositis ossificans traumatica in young children: report of three cases and review of the literature. Pediatr Radiol. 2000; 30: 451-9.

4. Woolar JA, Beirne JC, Triantafyllou A. Myositis ossificans traumatica of sternocleidomastoid muscle presenting as cervical lymph-node metastasis. Int J Oral Maxillofac Surg. 1995; 24: 170-3.
5. Yazici M, Etensel B, Gursoy MH, Aydogdu A, Erkus M. Nontraumatic myositis ossificans with an unusual location: case report. J Pediatr Surg. 2002; 37: 1621-2.

6. Kim JT, Yoon YH, Baek WK, Han JY, Chu YC, Kim HJ. Myositis ossificans of the chest wall simulating malignant neoplasm. Ann Thorac Surg. 2000; 70: 1718-20.

7. Nuovo MA, Norman A, Chumas J, Ackerman LV. Myositis ossificans with atypical clinical, radiographic, or pathologic findings: a review of 23 cases. Skelet Radiol. 1992; 21: 87-101.

8. Cushner FD, Morwessel RM. Myositis ossificans traumatica. Orthoped Rev 1992; 21: 1319-26.

9. Parkash H, Goyal M, Delhi N. Myositis ossificans of medial pterygoid muscle. Oral Surg Oral Med Oral Pathol. 1992; 73: 27-8.

10. Takayuki A, Hiroyuki N, Yoshihide O, Kazuo S. Myositis ossificans traumatica of the masticatory muscle: review of the literature and report of a case. J Oral Maxillofac Surg. 2002; 60: 1083-8.

11. Ogilvie-Harris DJ, Fornasier VL. Pseudomalignant myositis ossificans: Heterotopic new-bone formation without a history of trauma. J Bone Joint Surg Am. 1980; 62: 1274-83.

12. Kusuma S, Lourie GM, Lins RE. Myositis ossificans of the hand. J Hand Surg. 1999; 24: 128-30.

13. Wieder DL. Treatment of myositis ossificans with acetic acid iontophoresis. Phys Ther. 1992; 72: 133-7.

14. Steidl L, Ditmar R. Treatment of soft tissue calcifications with magnesium. Acta Univ Palacki Olomuc Fac Med. 1991; 130: 273-87.

15. Spinazze RP, Heffez LB, Bays RA. Chronic, progressive, limitation of mouth opening. J Oral Maxillofac Surg. 1998; 1178-86.

16. Mulherin D, Schow CE. Traumatic myositis ossificans after genioplasty. J Oral Surg. 1980; 38: 786-9.

17. Resnick D. Soft tissues. In: Diagnosis of Bone and Joint Disorders. 3rd edn. Philadelphia: W.B. Saunders; 1995. p. 4577-84. 